\title{
A Tribute to Gerald James Larson (1938-2019)
}

\section{Barbara A. Holdrege ${ }^{1}$}

Received: 25 May 2019 / Accepted: 16 September 2019/Published online: 8 January 2020

(C) Springer Nature Switzerland AG 2020

The Department of Religious Studies at the University of California, Santa Barbara, celebrates the life and legacy of Professor Emeritus Gerald James Larson, who passed away at the age of 81 on April 27, 2019, with his beloved wife, Claire, and his daughters at his side.

After obtaining his M.Div. from Union Theological Seminary in 1963 and his Ph.D. in the History of Religions and Comparative Philosophy from Columbia University in 1967, Professor Larson was a post-doctoral research scholar in the College of Indology at Banaras Hindu University in Varanasi, India, in 1968-1969 and served on the faculty in Religious Studies at the University of Tennessee, Knoxville, from 1967 to 1970 . He joined the Department of Religious Studies at UC Santa Barbara in 1970 and served with distinction as the Chair of the department (1971-1976), Assistant Vice Chancellor and Associate Vice Chancellor for Academic Affairs (1979-1982), founding Director of the Interdisciplinary Humanities Center (1987-1988), and Director of Academic Programs for the India Center of the UC Education Abroad Program at Delhi University (1984-1991).

Following his retirement from UCSB in 1995, Professor Larson served as the Rabindranath Tagore Professor of Indian Cultures and Civilizations and Director of the India Studies Program at Indiana University, Bloomington, from 1995 to 2003. Since 2011, he served part-time as a Visiting Research Professor in the Program in Religious Studies at the University of California, Irvine. His broader contributions to the academy included serving as the Vice President and President of the Society for Asian and Comparative Philosophy (1976-1977, 1982-1985) and Chair of the Committee on Research and Scholarship, American Academy of Religion (1993-1999).

Professor Larson was an internationally renowned scholar of the philosophies, religions, and cultures of India. As one of the world's foremost authorities on the Sāmkhya and Yoga systems of religious thought, he contributed to the historical and philosophical understanding of these traditions through a range of seminal works, including Classical Sāmkhya: An Interpretation of Its History and Meaning (1969; 2nd rev. ed. 1979), Sāmkhya: A Dualist Tradition in Indian Philosophy (1987, co-

Barbara A. Holdrege

holdrege@religion.ucsb.edu

1 University of California, Santa Barbara, Santa Barbara, CA 93106, USA 
edited with Ram Shankar Bhattacharya), and Yoga: India's Philosophy of Meditation (2008, co-edited with Ram Shankar Bhattacharya), and culminating in the crowning achievement of his career-the publication in 2018 of Classical Yoga Philosophy and the Legacy of Sämkhya. In recognition of Professor Larson's groundbreaking contributions to the study of the philosophies of India, a collection of essays by nineteen scholars was published in his honor in 2005, Theory and Practice of Yoga: Essays in Honour of Gerald James Larson.

Professor Larson also made significant contributions to our understanding of the complex intersections of religion, politics, and law in modern India through his works India's Agony Over Religion (1995) and Religion and Personal Law in Secular India: A Call to Judgment (2001, editor). His wide-ranging publications also include an edited volume on the cross-cultural philosophy of religion, Interpreting Across Boundaries: New Essays in Comparative Philosophy (1988, co-edited with Eliot Deutsch), and two art catalogues, In Her Image: The Great Goddess in Indian Asia and the Madonna in Christian Culture (1980, co-edited with Pratapaditya Pal and Rebecca Gowen) and Changing Myths and Images: Twentieth Century Popular Art in India (1997, co-edited with Pratapaditya Pal).

Those who knew him remember Gerry as a brilliant and dedicated scholar, a wise and generous mentor, and a beloved friend. He will be deeply missed by his colleagues, students, friends, and family.

Publisher's Note Springer Nature remains neutral with regard to jurisdictional claims in published maps and institutional affiliations. 